\title{
A Review of Necrotauliids from the Triassic/Jurassic of England (Trichoptera: Necrotauliidae)
}

\author{
Ulysses Thomson $\mathbb{D D}^{1,2}$ Andrew J. Ross, ${ }^{2,3}$ and Robert A. Coram ${ }^{1,4}$ \\ ${ }^{1}$ School of Earth Sciences, University of Bristol, Life Sciences Building, Tyndall Ave., Bristol BS8 1TQ, UK \\ ${ }^{2}$ Department of Natural Sciences, National Museum of Scotland, Chambers St., Edinburgh EH1 1JF, UK \\ ${ }^{3}$ Department of Earth Sciences, Natural History Museum, Cromwell Road, London SW7 5BD, UK \\ ${ }^{4}$ British Fossils Unit 2, Bailey Gate Industrial Estate, Sturminster Marshall, Wimborne, Dorset BH21 4DB, UK
}

Correspondence should be addressed to Ulysses Thomson; ulyssesthomson@icloud.com

Received 27 November 2017; Revised 9 February 2018; Accepted 7 March 2018; Published 9 May 2018

Academic Editor: Ai-Ping Liang

Copyright (c) 2018 Ulysses Thomson et al. This is an open access article distributed under the Creative Commons Attribution License, which permits unrestricted use, distribution, and reproduction in any medium, provided the original work is properly cited.

\begin{abstract}
Species previously attributed to Necrotauliidae are revised from the Late Triassic and Early Jurassic of England based on examination of type specimens and non-type material. The necrotauliids have been considered as a basal family of caddisflies (Trichoptera) or as a paraphyletic assemblage of stem-amphiesmenopterans. Herein a new genus, Austaulius, is erected which includes all Lilstock Formation\Lower Lias material from England; the previously described species are synonymized with A. furcatus and a new species, A. haustrum, is described from the Dorset Coast, the holotype of which preserves synapomorphic traits of the Trichoptera not previously described suggesting that the family is trichopteran. The type genus remains Necrotaulius and type species N. parvulus (Geinitz, 1884) from the type locality of Dobbertin, Germany. One species of Necrotaulius is represented in the UK, N. parvulus, which is found in the Upper Lias.
\end{abstract}

\section{Introduction}

Trichoptera (caddisflies) are a relatively small order of insects with 13,000 living species [1] and 642 fossil species according to Morse [2]. Although more fossil species have been described since, for example, [3], the online Palaeobiology Database (PBDB-http://fossilworks.org) lists 553 valid species. Adults have a similar morphology to moths, highlighting their close relationship with the Lepidoptera. However, whereas Lepidoptera ("scale-winged") have a layer of scales on their wings, Trichoptera ("hairy-winged") usually have a layer of hairs, but there are exceptions and some caddisflies are known to have scales [4]. Most larvae are aquatic although some can be semiaquatic or terrestrial and they are among the few insects to have radiated into the marine realm [5]. Trichopterans from the early Mesozoic are usually preserved as isolated wings and are difficult to distinguish from early Lepidoptera and stem-Amphiesmenoptera.

Trichoptera and Lepidoptera evolved from stem-Amphiesmenoptera early in the Mesozoic [6] with the extinct family Necrotauliidae filling an undefined space within or between the stem-Amphiesmenoptera and the evolving Lepidoptera and Trichoptera. The family Necrotauliidae was erected by Handlirsch [7], who described the genus Necrotaulius with seven species, five of which were new, plus two British species named by Giebel [8] that were transferred from the mecopteran (scorpionfly) genus Orthophlebia, and the genus Mesotrichopteridium with one species, M. pusillum. Tillyard [9] made N. liasinus (Giebel) a junior synonym of $N$. furcatus (Giebel) and described four new species: $N$. westwoodi, N. stigmaticus, N. apicalis, and N. pygmaeus, from British material. Handlirsch [10] added 10 new species from the Upper Lias (Toarcian) of Germany. He named one species as N.pygmaeus, but this was identified as a homonym and renamed N. ulmeri [11]. Ansorge [12] transferred $N$. parvulus (Geinitz) from the genus Orthophlebia and made $N$. pygmaeus Tillyard, 1933, a junior synonym. Only Necrotaulius has been hitherto described from the Triassic/Jurassic of England. 
Necrotauliidae has been described as a paraphyletic assemblage of species containing basal Trichoptera, basal Lepidoptera, and advanced stem-Amphiesmenoptera [6, 13]. A revision of the German Upper Lias (Toarcian) material was carried out by Ansorge $[12,14]$ and several major taxonomic changes were proposed including removing Necrotauliidae from Trichoptera completely. Previously named species within the family from Germany were restricted to N. parvulus and Mesotrichopteridium intermedium and it was suggested that the latter may not be a necrotauliid [12] but that the Lower Jurassic material from England and Kyrgyzstan needed revising first to properly understand affinities. The genus was likened to Prorhyacophila (in Prorhyacophilidae Riek as per [15]) and although the holotype was not examined it was suggested that Prorhyacophila was a junior synonym of Mesotrichopteridium. The following genera were considered as Lepidoptera by Ansorge [12]: Archiptilia Handlirsch; Epididontus Handlirsch; Metarchitaulius Handlirsch; Nannotrichopteron Handlirsch; Palaeotaulius Handlirsch; Pararchitaulius Handlirsch; Parataulius Handlirsch; Paratrichopteridium Handlirsch; and Pseudorthophlebia Handlirsch. It was reiterated by Ansorge [14] that Archiptilia, Nannotrichopteron, Pararchitaulius, Parataulius, and Pseudorthophlebia were Lepidoptera because they had scales on the wing surface, and that Paratrichopteridium was either a hindwing of Liadotaulius or belonged to Lepidoptera. They were all subsequently listed as polyphyletic Necrotauliidae under Lepidoptera [16].

?N. maior, ?Paratrichopteridium areatum, Liadotaulius acutipennis, $P$. breve, and ?P. angustum were synonymized with Liadotaulius maior [12] and it was proposed that this was the oldest known true trichopteran with uncertain familial taxonomy. The genus was provisionally placed in Philopotamidae [17] based on similarities in forewing venation and additional species have been included [18]. A possible philopotamid was described from the Ladinian $\backslash$ Carnian of Madygen, Kyrgyzstan, and prorhyacophilids and necrotauliids have also been described from this locality; thus these are potentially the oldest true Trichoptera (see [19]).

The genus Acisarcuatus was described from the Middle Jurassic of China and placed in the Necrotauliidae [20]. The authors were able to include body characteristics which they suggested supported the family's placement in the Trichoptera. The specimen is well preserved, showing genitalia and maxillary palps, and [20] suggested that the presence of harpagones ("claspers") is a synapomorphy of Trichoptera, citing [21, 22]. Both papers do mention the presence of harpagones but neither indicate that this is synapomorphic for the Trichoptera. Even if they meant that the form of the harpagones was synapomorphic (regularly curving towards the middle, narrowing at apex), this would still not be a true synapomorphy as this character is also recorded in other orders such as Diptera [23] and Raphidioptera [24]. Also, multiple variations including 1-segmented and 2-segmented forms and forms which are narrower at the base have been recorded in Trichoptera [22].

The main issue with the higher taxonomy of Trichoptera is that much of the classification is based on larval morphology of extant species. Several characters have been proposed as synapomorphies for Trichoptera and these are listed by Holzenthal et al. [22] as follows: larvae aquatic and apneustic (no open spiracles) so respiration is epidermal, often by filamentous abdominal gills; larval tentorium reduced; larval antennae greatly reduced; larval abdominal segments 1-9 are without ventral prolegs; larval abdominal segment 9 is with dorsal tergite. Only one character was listed as being synapomorphic for adults: the formation of a haustellum, a modified form of mouthparts not seen in any other order. Other authors agree that the haustellum as found in Trichoptera is the only unequivocal autapomorphy of adult Trichoptera [25]. A similar structure is found in in the non-Glossatan Lepidoptera and is assumed to be present in Tarachoptera, but it is small and not visible externally [26]. The haustellum has not previously been reported in any specimen of necrotauliid; coupled with the similarity of wing venation with other basal amphiesmenopterans it has been difficult to say with any degree of certainty whether Necrotauliidae do belong to Trichoptera $[18,20]$ or are stemamphiesmenopterans $[12,14]$.

There is a forewing venation character which has been proposed as diagnostic of the Trichoptera, the CuP tip desclerotised and abruptly bending towards the posterior margin [12]. Kristensen [27] noted the character as potentially important for indicating whether an amphiesmenopteran of uncertain affinity was of the trichopteran lineage or not, but it is not a synapomorphy and is limited in its diagnostic use as it is homoplasious, having evolved separately in different lineages of Trichoptera, some mecopterans (e.g., Bittacidae), and some basal Mecopterida (Microptysmatidae). Not all extant Trichoptera demonstrate this and a curved CuP can also be seen in some species of micro moths (see [28]); thus we do not regard it as a reliable character for separating Trichoptera from Lepidoptera.

Also listed by Liu et al. [20] were Necropsis Hong and Karatauliodes Sukatsheva; however the former was regarded as belonging to Mecoptera and the latter was designated as a junior synonym of Necrotaulius [18]. Zhang et al. [18] also described a new species of Acisarcuatus and listed the following additional genera within the Necrotauliidae: Cretotaulius Sukatsheva; Karataulius Sukatsheva; Mesotrichopteridium Handlirsch; Necrotaulius Handlirsch; Pteromixanum Sukatsheva and Jarzembowski; and Scyphindusia Sukatsheva. Of these the latter is based on a larval case so is not useful for a discussion on wings. Carpenter [29] also listed Liadoptilia Handlirsch, Liadotaulius Handlirsch, and Phryganeidium Westwood; however, Liadoptilia was regarded as unplaced in Amphiesmenoptera [12] and Liadotaulius was tentatively regarded as belonging to the Philopotamidae [18].

Phryganeidium Westwood (erected for P. pytho Westwood, 1854 [30] from the Lower Cretaceous of Dorset, UK) has been confused with Phryganidium Geinitz (erected for $P$. balticum Geinitz, 1880 [31] from the Lower Jurassic of Germany). It is possible that Geinitz misspelt Westwood's genus, and subsequently $P$. pytho was listed under Phryganidium by Scudder (1891, p. 161) [32]. However, Geinitz does not refer to Westwood under the description of $P$. balticum, even though he refers to other trichopteran specimens figured in Brodie, 1845 [33] ("Orthophlebia" furcata and liasina), and he does 
refer to Westwood when discussing other new species in the same paper. Geinitz said "Unfortunately, I lack both the necessary literature and a comparative collection of living insects, and for the time being I have to be modest in using the general family name Phryganidium for this genus." This is ambiguous but does not rule out that he was not erecting a new name, and he erects other new generic names in the same paper but does not indicate that they are new. P. balticum was moved to the hemipteran genus Fulgoridium Handlirsch by Handlirsch (1907, p. 496) [7], where it still resides [34]; and $P$. pytho was placed in the Jurassic trichopteran genus Mesotrichopteridium Handlirsch by Handlirsch (1907, p. 616) [7]. P. pytho is still a valid species and although Westwood's figures are generally unreliable, his figure of the holotype (pl. 18, Figure 31) clearly shows far fewer branches than Fulgoridium and it differs from Mesotrichopteridium in having a branched R1. Thus, we regard Phryganidium Geinitz (type species $P$. balticum) as a junior synonym of Fulgoridium within the order Hemiptera and Phryganeidium Westwood (type species P. pytho) as a valid genus within the order Trichoptera. Phryganeidium pytho has a branched R1 which rejects the species from the Necrotauliidae according to the emended diagnosis provided below. It clearly needs to be redescribed and until that happens we regard it as Trichoptera: family uncertain.

Herein we revise the taxonomy of Late Triassic and Early Jurassic Necrotauliidae from England. Most of these specimens are isolated wings, but several do preserve other body parts including one specimen from the Sinemurian of Dorset in which an external haustellum is preserved suggesting that the Necrotauliidae are trichopterans and not stem-Amphiesmenoptera. A new genus was also found, and although it is imperative to distinguish it from all the other genera listed above, a detailed redescription of these taxa is beyond the scope of this study. A robust definition for the Necrotauliidae based primarily on the type genus Necrotaulius is required and we have attempted to supply this based on the examination of some holotypes and nonholotype material and published descriptions. All known species of Necrotauliidae are listed in Table 1 as are the species previously associated with Necrotauliidae but are now excluded.

\section{Materials and Methods}

There are 57 specimens identified as Necrotauliidae from the Upper Triassic and Lower Jurassic of Britain, all from England. 22 of these are held at the Natural History Museum, London (NHMUK), 15 of which are in the collection of Rev. Peter Bellinger Brodie, two were collected by Edmund Jarzembowski, two by Sydney Buckman, one by David Sole, and two more recently by RAC; 13 are held at the Yorkshire Museum, York (YORYM), all of which are in the Brodie collection; one is held at the Oxford University Museum of Natural History (OUMNH) from the Rev. Hope collection; one is held at the Somerset Heritage Centre for Taunton Museum (TTNCM) from the Charles Moore collection. Additional material was examined from the Paleontological Institute of the Russian Academy of Sciences, Moscow (PIN), the Ernst-Moritz-Arndt Universität, Greifswald (EMAUG), and the Nanjing Institute of Geology and Palaeontology, Chinese Academy of Sciences (NIGPAS).

All specimens were examined first-hand by the primary author except where specifically stated. Examinations were carried out using a light microscope (different model at each museum) and photographs were taken with a digital camera attached to a Leica microscope where possible, or with a Nikon D3300 with AF-S Micro Nikkor $40 \mathrm{~mm}$ macro lens attached to a stand. Light sources were altered and applied at various angles to capture as much of the preserved venation as possible and where applicable alcohol was used to further highlight venation. Drawings were made from photographs using the Serif DrawPlus X6 graphics package. The locality map (Figure 1) was plotted on the "light grey standard" base map in ArcGIS desktop 10.0; design alterations were made in Serif DrawPlus X6.

2.1. Nomenclatural Acts. The new names contained in this article are available under the International Code of Zoological Nomenclature. This work and the nomenclatural acts it contains have been registered in ZooBank. ZooBank Life Science Identifier (LSID) for this publication is: urn:lsid: zoobank.org:pub: 7528E2B8-E53D-4395-A73F-BAFD3F5A20AF. The LSID registration and any associated information can be viewed in a web browser by adding the LSID to the prefix "http://zoobank.org/."

\section{Localities and Ages}

Necrotauliids have been collected from 12 localities in the UK all of which are found in England (Figure 1). Most of these localities (those that are inland) are historical and have not been collected from for over 100 years. The literature for the stratigraphy of the insect bearing horizons is equally outdated and so we aim to update the ages of these historical localities to current geological nomenclature. The Rhaetian localities of Brown's Wood, Warwickshire and Apperley, Forthampton, and Wainlode Cliff (Gloucestershire) along with the Hettangian localities of Binton (Warwickshire) and Copt Heath (Birmingham) and the Toarcian locality of Strawberry Bank, Ilminster (Somerset), were previously discussed [35]. The Rhaetian localities of Aust Cliff and Brockeridge (Gloucestershire) and the Sinemurian locality of Monmouth Beach, Lyme Regis (Dorset) were also previously discussed [36]. The localities not previously discussed are described below.

3.1. Blue Anchor, Somerset [National Grid Reference ST 033 435] (Rhaetian). A section at this coastal locality was described and figured by Hauser and Martill [37] showing the succession from the Norian Mercia Mudstone Formation through the entire Rhaetian and into the Lower Lias Blue Lias Formation at the top of the cliff. This is the type locality for the lower Rhaetian Blue Anchor Formation [38]. Several insects have been collected from this site by RAC from loose rocks on the foreshore which are consistent with the limestones of the Cotham Member of the Lilstock Formation. 
TABle 1: Known species of Necrotauliidae and previous species now associated with the lepidopteran lineage. $\mathrm{T}_{3}$ : Late Triassic; $\mathrm{J}_{1}$ : Early Jurassic; $\mathrm{J}_{2}$ : Middle Jurassic; $\mathrm{J}_{3}$ : Late Jurassic; $\mathrm{K}_{1}$ : Early Cretaceous.

\begin{tabular}{|c|c|c|c|c|}
\hline Genus & Species & Author & Age & Locality \\
\hline \multicolumn{5}{|c|}{ Trichoptera: Necrotauliidae } \\
\hline Acisarcuatus & locellatus & Zhang et al., 2016 & $\mathrm{~J}_{2}$ & Daohugou, China \\
\hline Acisarcuatus & variradius & Liu et al., 2014 & $\mathrm{~J}_{2}$ & Daohugou, China \\
\hline Austaulius & furcatus & (Giebel, 1856) & $\mathrm{T}_{3}$ & Aust Cliff, UK \\
\hline Austaulius & haustrum & sp. nov. & $\mathrm{J}_{1}$ & Monmouth Beach, UK \\
\hline Cretotaulius & ultimus & Sukatsheva, 1982 & $\mathrm{~J}_{3}$ & Unda, Russia \\
\hline Karataulius & aeternus & Sukatsheva, 1968 & $\mathrm{~J}_{2} / \mathrm{J}_{3}$ & Karatau, Kazakhstan \\
\hline Mesotrichopteridium & intermedium & (Handlirsch, 1907) & $\mathrm{J}_{1}$ & Dobbertin, Germany \\
\hline Necrotaulius & fascialatus & Hong, 1983 & $\mathrm{~J}_{2}$ & Xiaofanzhangzi, China \\
\hline Necrotaulius & kritus & Lin, 1986 & $\mathrm{~J}_{3}$ & Zhongshan, China \\
\hline Necrotaulius & kubekovi & Sukatsheva, 1985 & $\mathrm{~J}_{2}$ & Kubekovo, Russia \\
\hline Necrotaulius & mantellorum & Jarzembowski, 1991 & $\mathrm{~K}_{1}$ & Capel, UK \\
\hline Necrotaulius & minutissimus & Sukatsheva, 1990 & $\mathrm{~J}_{3}$ & Daya, Russia \\
\hline Necrotaulius & minutus & (Sukatsheva, 1968) & $\mathrm{J}_{2} / \mathrm{J}_{3}$ & Karatau, Kazakhstan \\
\hline Necrotaulius & parvulus & (Geinitz, 1884) & $\mathrm{J}_{1}$ & Dobbertin, Germany \\
\hline Necrotaulius & proximus & Sukatsheva, 1973 & $\mathrm{~T}_{2} / \mathrm{T}_{3}$ & Madygen, Kyrgyzstan \\
\hline Necrotaulius & qingshilaense & Hong, 1984 & $\mathrm{~K}_{1}$ & Shidongzi, China \\
\hline Necrotaulius & tener & Sukatsheva, 1990 & $\mathrm{~J}_{3}$ & Unda, Russia \\
\hline Prorhyacophila & colliveri & Riek, 1955 & $\mathrm{~T}_{3}$ & Mt. Crosby, Australia \\
\hline Prorhyacophila & furcata & Sukatsheva, 1973 & $\mathrm{~T}_{2} / \mathrm{T}_{3}$ & Madygen, Kyrgyzstan \\
\hline Pteromixanum & inviolatum & Sukatsheva \& Jarzembowski, 2001 & $\mathrm{~K}_{1}$ & Durlston Bay, UK \\
\hline Pteromixanum & poxwellense & Sukatsheva \& Jarzembowski, 2001 & $\mathrm{~K}_{1}$ & Poxwell, UK \\
\hline Pteromixanum & purbeckianum & Sukatsheva \& Jarzembowski, 2001 & $\mathrm{~K}_{1}$ & Durlston Bay, UK \\
\hline Pteromixanum & ruderatum & Sukatsheva \& Jarzembowski, 2001 & $\mathrm{~K}_{1}$ & Durlston Bay, UK \\
\hline Scyphindusia & hydroptiliformis & Sukatsheva, 1985 & $\mathrm{~J}_{2} / \mathrm{J}_{3}$ & Bolshoy, Russia \\
\hline \multicolumn{5}{|c|}{ Trichoptera: family uncertain } \\
\hline Phryganeidium & pytho & Westwood, 1854 & $\mathrm{~K}_{1}$ & Durlston Bay, UK \\
\hline \multicolumn{5}{|c|}{ Lepidoptera: family uncertain } \\
\hline Architipula & ovata & Handlirsch, 1939 & $\mathrm{~J}_{1}$ & Dobbertin, Germany \\
\hline Epididontus & geinitzianus & Handlirsch, 1939 & $\mathrm{~J}_{1}$ & Dobbertin, Germany \\
\hline Metarchitaulius & longus & Handlirsch, 1939 & $\mathrm{~J}_{1}$ & Dobbertin, Germany \\
\hline Nannotrichopteron & gracile & Handlirsch, 1907 & $\mathrm{~J}_{1}$ & Dobbertin, Germany \\
\hline Palaeotaulius & vicinus & Handlirsch, 1939 & $\mathrm{~J}_{1}$ & Dobbertin, Germany \\
\hline Pararchitaulius & ovalis & Handlirsch, 1939 & $\mathrm{~J}_{1}$ & Dobbertin, Germany \\
\hline Parataulius & jurassicus & Handlirsch, 1939 & $\mathrm{~J}_{1}$ & Dobbertin, Germany \\
\hline Pseudorthophlebia & platyptera & Handlirsch, 1907 & $\mathrm{~J}_{1}$ & Dobbertin, Germany \\
\hline \multicolumn{5}{|l|}{ Amphiesmenoptera } \\
\hline Paratrichopteridium & efossum & Handlirsch, 1939 & $\mathrm{~J}_{1}$ & Dobbertin, Germany \\
\hline Paratrichopteridium & costale & Handlirsch, 1939 & $\mathrm{~J}_{1}$ & Dobbertin, Germany \\
\hline
\end{tabular}

3.2. Dumbleton/Alderton, Gloucestershire [SP 006 345] (Toarcian). There are several hills in Gloucestershire from which Toarcian aged insects have been collected and the most productive are in the Dumbleton-Alderton area, although there has been some confusion over the names of the locality/ies. "Dumbleton" and "Alderton" have been described as separate localities [33] but this is not the case even though there are two hills in the area, "Alderton Hill" and "Dumbleton Hill." After seeking consultation from Michael Simms, a geologist local to the area, Palmer [39] treated them as the same locality, indicating that "Dumbleton pit" was not actually on Dumbleton Hill and was only $100 \mathrm{~m}$ away from "Alderton Hill quarry." Either way the insect horizon in both the pit and the quarry occupy the same stratigraphic position. Alderton/Dumbleton is a well-known locality for 


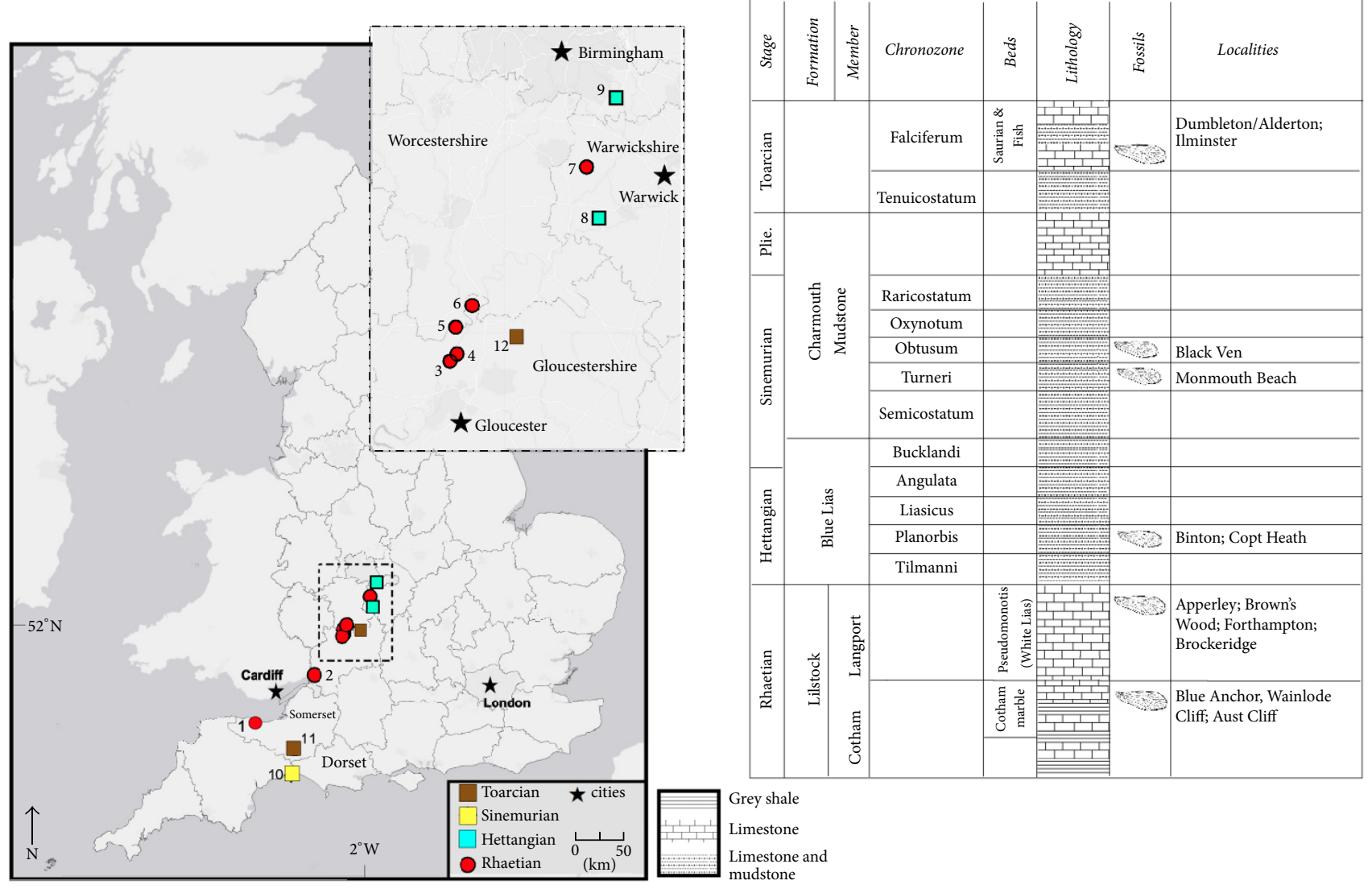

Figure 1: Locality map. (1) Blue Anchor, (2) Aust Cliff, (3) Wainlode Cliff, (4) Apperley, (5) Forthampton, (6) Brockeridge, (7) Brown's Wood, (8) Binton, (9) Copt Heath, (10) Monmouth Beach, (11) Ilminster, and (12) Alderton Hill/Dumbleton Pit.

insects from the lower Toarcian fish beds ("Fish and insect beds", "Saurian and fish beds") which are found in the Whitby Mudstone Formation [40]. The fish beds are described as laminated limestone nodules overlaying paper shales [41] and are contiguous with the fish beds found at Ilminster [42] being found in the falciferum Ammonite Zone.

\section{Systematic Palaeontology}

Superorder Amphiesmenoptera Kiriakoff, 1948 [43]

Order Trichoptera Kirby, 1813 [44]

Family Necrotauliidae Handlirsch, 1907 [7]

$=$ Prorhyacophilidae Riek, 1955 [45]

Emended Diagnosis. Forewings with the following combination of characters: R1 simple; Rs with two forks (each with two branches); $\mathrm{M}$ with two forks (each with two branches); $\mathrm{CuA}$ forked; $\mathrm{m}$-cu cross-vein (or base of $\mathrm{CuA}$ ) present; anal veins 2 and 3 merge, then merge with Al which terminates on the posterior margin. In hindwing, MP simple and anal veins are simple, terminating on the posterior margin. Hairs present on forewing and around wing-margins of both foreand hindwings (if preserved).
Discussion. Ansorge [12] considered Prorhyacophila a junior synonym of Mesotrichopteridium; however this has not been followed by others. Certainly, from the diagnosis provided above it is not possible to exclude the type species Prorhyacophila colliveri Riek, 1955 from the Necrotauliidae; thus the family Prorhyacophilidae needs to be regarded as a junior synonym. Prorhyacophila and Mesotrichopteridium differ in the positions of cross-veins so are kept separate here. The Permian species Prorhyacophila rasnitsyni Sukatsheva \& Aristov, 2013 in [15, Figure 68(e)] has a branched R1 thus it is rejected from the Necrotauliidae and Prorhyacophila.

Description. In addition to the diagnosis of the forewing Sc is either simple or with one or two anterior oblique branches; Sc-r, r-m, m-cua, cua-cup, and al-a2 cross-veins may be present, though may not be visible on poorly preserved specimens.

Remarks. Hairs are not always preserved as most specimens are not well preserved but there are examples of both Necrotaulius and Austaulius with hairs (Figures 2(b)-2(d)). The family is extinct and only known from the Triassic to Cretaceous but as only preserved characters can be included in the diagnosis there may be superficial similarity with some extant taxa.

\section{Genus Necrotaulius Handlirsch [7]}



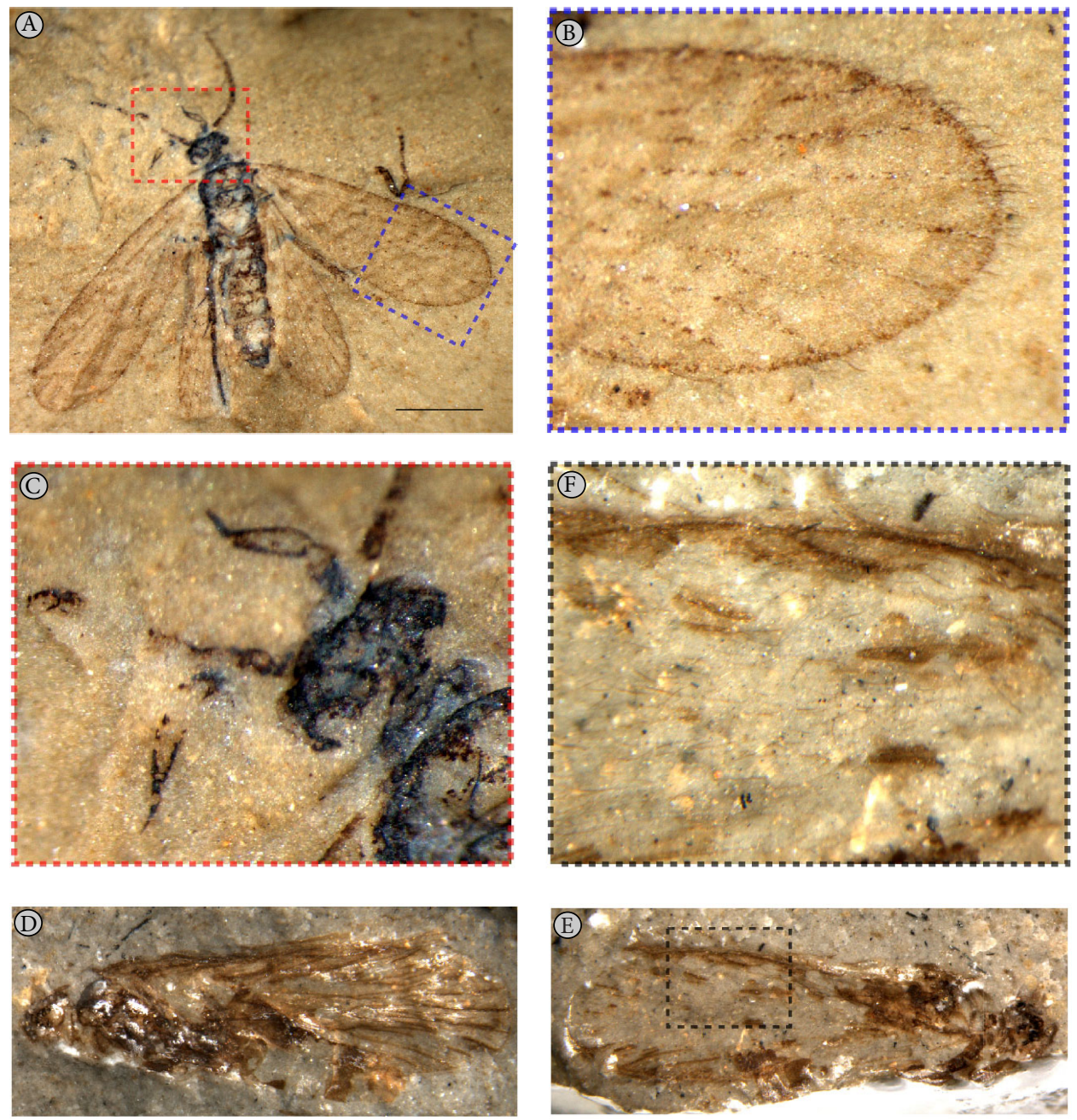

FIgURE 2: Two examples of necrotauliid wings with hairs and labial palps: (a) Necrotaulius tener Sukatsheva, 1990 from Daya, Russia (PIN 3015/819); (b) hairs; (c) labial palps; (d) Austaulius furcatus (NHMUK II 3104 a); (e) counterpart NHMUK II 3104 b; (f) hairs on NHMUK II $3104 \mathrm{~b}$ magnified.

Type Species. Necrotaulius parvulus (Geinitz, 1884) [46]

Emended Diagnosis. Sc simple, r-m cross-vein absent, CuA connected by "Y-shape" to $\mathrm{M}$ and CuP; labial palps longer, second segment more elongate than first or third (Figure $2(\mathrm{c}))$.

Remarks. The apex of CuP does not seem to be desclerotised in the British specimens of this genus and more gently curves towards the posterior margin

\section{Necrotaulius parvulus (Geinitz, 1884) [46]}

Holotype. EMAUG 119/7 (see [12]) from the Falciferum Chronozone of the Posidonia Shale Formation (lower Toarcian), Schwinz near Dobbertin, Germany.

Additional Material. See [12] for list of lower Toarcian German specimens. British Toarcian: NHMUK I.15014 (holotype of Necrotaulius pygmaeus Tillyard, Figure 3) and I.11425, both Dumbleton and TTNCM 39/2011/0733, Ilminster, Somerset.

Remarks. The three British specimens match the diagnosis and description of this species as provided by Ansorge [12]. Sohn et al. [16] indicated that Ansorge [12] redefined Necrotaulius to only include the type species $N$. dobbertinensis but this is incorrect. Ansorge designated N. dobbertinensis a junior synonym of $N$. parvulus based on the latter's date priority.

Genus Austaulius gen. nov.

urn:lsid:zoobank.org:act:D1FBC755-D8BD-45DA9934-9C78F029DF8E

Type Species. Austaulius furcatus (Giebel, 1856) [8]

Etymology. Aust- after the holotype locality for the type species, and-taulius after the suffix for Necrotaulius. 

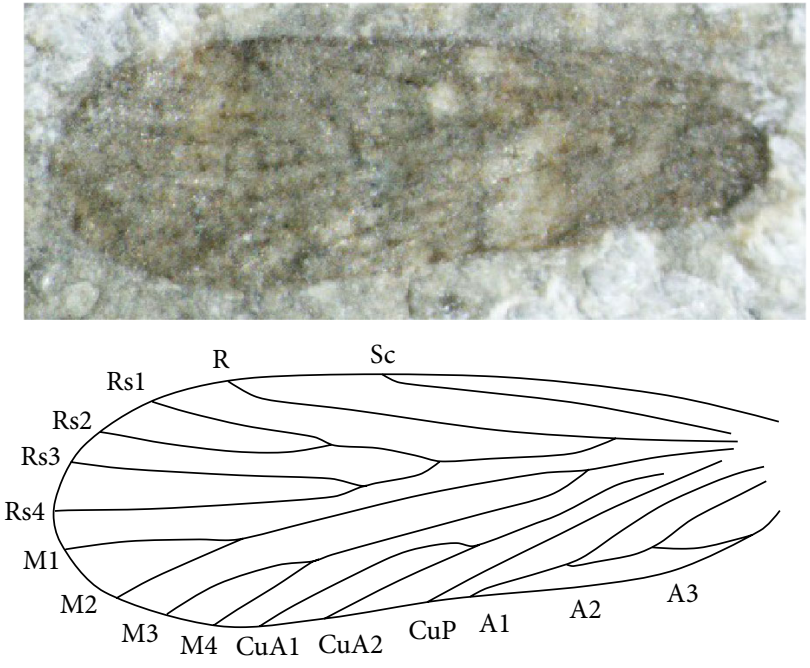

FIgure 3: Example of English Necrotaulius parvulus (Geinitz, 1884), NHMUK I.15014 from Dumbleton pit, Gloucestershire (previous holotype of Necrotaulius pygmaeus Tillyard, 1933). Scale bar $=1 \mathrm{~mm}$.

Diagnosis. Sc with 1 anterior branch, r-m cross-vein absent, $\mathrm{CuA}$ fuses with $\mathrm{M}$ for a short distance near the base then with an oblique cross-vein connecting $\mathrm{MP}+\mathrm{CuA}$ to $\mathrm{CuP}$; labial palps shorter; second segment about same length as first segment (Figure 4).

Remarks. Clearly the form of CuA was misinterpreted by Tillyard [9] and begs the question as to whether any other Necrotaulius species have been misinterpreted. Other Necrotaulius holotypes were checked in person by the senior author. The following do not possess the diagnostic form of $\mathrm{CuA}$ as seen in Austaulius: N. parvulus (Geinitz) (EMAUG 119/7) from the Upper Lias of Germany; N. kubekovi Sukatsheva (PIN 1255/193) from the Middle Jurassic of Russia; N. minutissimus Sukatsheva (PIN 3063/742), N. minutus (Sukatsheva) (PIN 2066/1303), and N. tener Sukatsheva (PIN 3015/819) (Figures 2(a)-2(c); also figured in [6], Figure 13.1 and [13], Figure 283) from the Late Jurassic of Russia and Kazakhstan and N. kritus Lin (NIGPAS 70078) from the Middle Jurassic of China. N. fascialatus Hong and N. qingshilaense Hong were described from the Late Jurassic and Early Cretaceous of China, respectively. Unfortunately, it is not known where Hong's holotypes are although researchers at NIGPAS have been searching for them (Wang Bo, pers. comm., 2016). Based on Hong's figures it appears that the basal area of the wing is not preserved in N. fascialatus ([47], Figure 46); the character may be present in N. qingshilaense ([47], Figure 47) but it is not at all clear; the holotype would need to be examined. N. mantellorum Jarzembowski (Booth Museum, Brighton 014897/8) was described from the Early Cretaceous of England [48]. It requires reexamination to confirm whether it belongs to Necrotaulius or not. One specimen (NHMUK II $3104 \mathrm{a}$ and b) was identified as Austaulius sp. indet. and is included because it preserves hair on the wings (Figures $2(d)-2(f))$.

\section{Austaulius furcatus (Giebel, 1856) [8] comb. nov.}

"Neuropterous insects" Westwood in Brodie (1845) [33], p. 127, pl. 9, Figures 16 and 17.

Orthophlebia furcata Giebel, 1856 [8] p. 261.

Orthophlebia liasina Giebel, 1856 [8] p. 261.

Orthophlebia furcata Giebel; Goss (1879) [49], p. 145.

Orthophlebia liasina Giebel; Goss (1879) [49], p. 145.

Orthophlebia furcata Giebel; Scudder (1891) [32], p. 156 (nos. 1024, 1025).

Orthophlebia liasina Giebel; Scudder (1891) [32], p. 157 (no. 1029).

Orthophlebia furcata Giebel; Woodward (1893) [50], p. 367.

Orthophlebia liasina Giebel; Woodward (1893) [50], p. 367.

Necrotaulius furcatus (Giebel); Handlirsch (1907) [7], p. 484, pl. 42, Figure 37.

Necrotaulius liasinus (Giebel); Handlirsch (1907) [7], p. 485 , pl. 42, Figure 38 .

Necrotaulius furcatus (Giebel); Tillyard (1933) [9], p. 62, Figures 23-25.

Necrotaulius stigmaticus Tillyard, 1933 [9], p. 65, Figure 27. syn. nov.

Necrotaulius westwoodi Tillyard, 1933 [9], pp. 64, 65, Figure 26. syn. nov.

Necrotaulius apicalis Tillyard, 1933 [9], p. 66, Figure 28. syn. nov.

Necrotaulius furcatus (Giebel); Willmann (1978) [51], p. 115.

Necrotaulius westwoodi Tillyard; Sukatsheva (1985) [52], p. 13, Figure 32.

Necrotaulius westwoodi Tillyard; Carpenter (1992) [29], p. 362, Figure 201,7.

Necrotaulius furcatus (Giebel); Jarzembowski (1999) [53], p. 159, text-Figures 18(A), 18(B).

Necrotaulius furcatus (Giebel); Jarzembowski and Palmer (2010) [54], p. 170, Figure 4.19.

Necrotaulius westwoodi Tillyard; Zhang et al. (2017) [18], p. 28, Figure 7(B).

Necrotaulius furcatus (Giebel); Zhang et al. (2017) [18], p. 28, Figure 7(C).

Holotype. YORYM YM 815/NHMUK I.11522 (Figure 4) from the Cotham Member of the Penarth Group (Rhaetian), Aust Cliff, Gloucestershire.

Remarks. The holotype of this species was originally reported as YM 815 [55] with the counterpart being sent to the "British Museum" (NHMUK) according to R. Wootton (note in specimen box at YORYM). NHMUK I.11522 was later reported as the holotype by Tillyard [9] who thought that the differences in the specimens were due to breakage after 


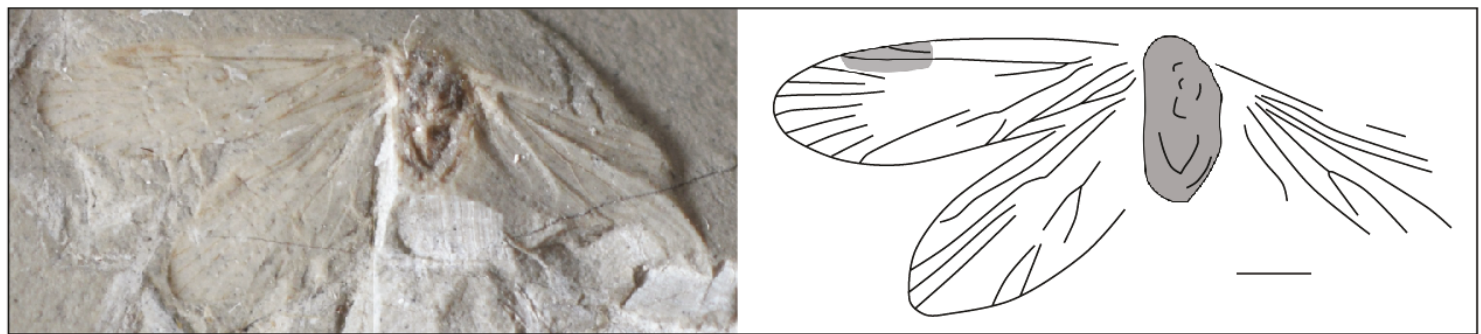

(a)

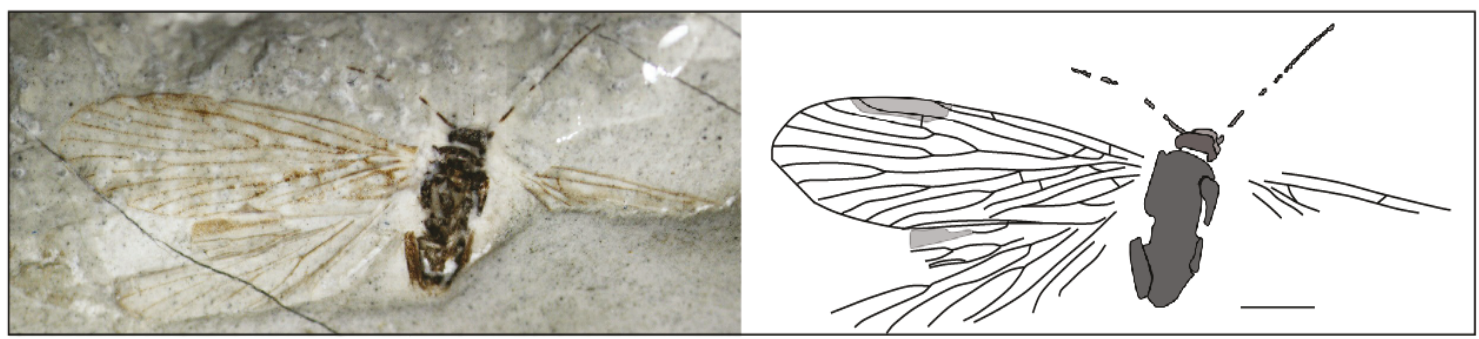

(b)

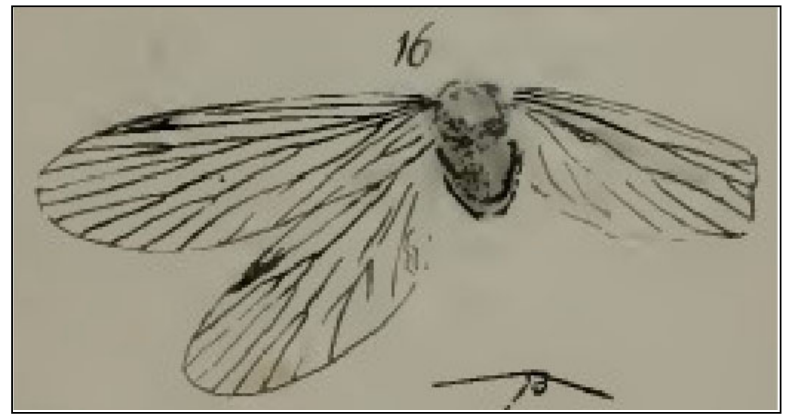

(c)

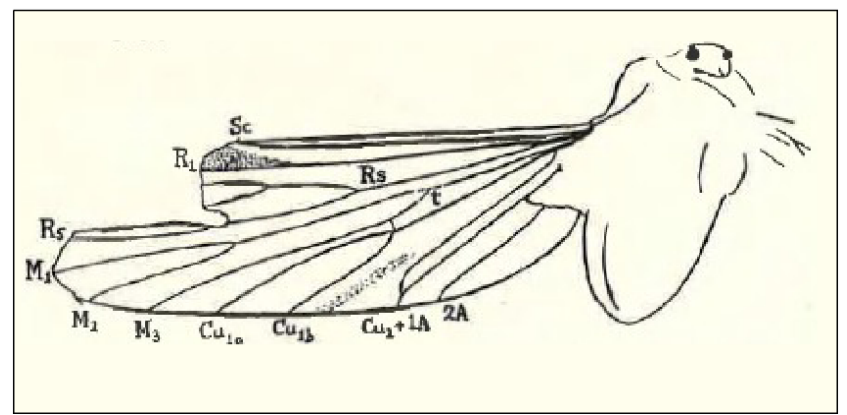

(d)

FIgURE 4: Holotype of Austaulius furcatus (Giebel, 1856) from Aust Cliff, Gloucestershire. (a) YORYM YM 815; (b) NHMUK I.11522; (c) original holotype figure in Brodie (1845, pl. 9, Figure 16); (d) figure of "holotype" in Tillyard (1933, Figure 25). Scale bars = $1 \mathrm{~mm}$.

the original holotype figure. However, based on the original figure of the holotype by Brodie ([33], pl. 9, Figure 16) and writing on the rock of the specimens, it is clear that the first report was correct. YM 815 matches the holotype figure by Brodie ([33], pl. 9, Figure 16) and written on the rock in Brodie's handwriting is "Pl 9 F 16." Figure 4 shows the specimens involved and copies of the figures from $[9,33]$. It is unclear why Tillyard figured I.11522 without the very prominent left forewing (Figure 4(d)); he did suggest that the specimen had broken since Brodie's original figure, so perhaps it was further prepared after Tillyard had figured it, revealing the forewing. Although the part and counterpart look different, there is a calcite vein that cuts diagonally across the hindwing at the same position in both parts.

Additional Material. Rhaetian: NHMUK I.11545, I.11544 (previously holotype of $O$. liasina, figd Brodie [33, pl. 9, Figure 17]), I.11534; YORYM: YM1984/7F, YM1984/6F, YM1984/1F from Aust Cliff; I.3081 from Wainlode Cliff (previous holotype of N. apicalis, Figure 5(a)); one other in the private collection of RAC collected from Blue Anchor. Hettangian:
I.11019 from Copt Heath; I.11584 from unknown locality in England ("W" on museum label) (previous holotype of $N$. stigmaticus Figure 5(b)); I.11761 (previous holotype of $N$. westwoodi, Figure 5(c)) and 11574 both from unknown localities in England.

Diagnosis. Forewings $4.3-5.6 \mathrm{~mm}$ in length, $1.4-1.8 \mathrm{~mm}$ in width. Anterior fork (F1) of Rs branching point is almost in line with the branching point of posterior fork (F2), or slightly distal.

Description. Holotype forewing $5.3 \mathrm{~mm}$ in length. It is an almost whole specimen with both forewings wholly preserved (one on each part); right hindwing nearly complete. Body, head, and antennae also preserved in the counterpart but poorly. One antenna with 15 antennomeres preserved including scape. In forewing Sc terminating on $\mathrm{C}$ just beyond mid-wing, with two cross-veins between Sc and C; R simple, reaching anterior margin in apical quarter of the wing within the pterostigma; oblique cross-vein near base between $\mathrm{R}$ and Sc; Rs splits from $\mathrm{R}$ in basal quarter further bifurcating into two forks of subequal length (posterior fork slightly longer 

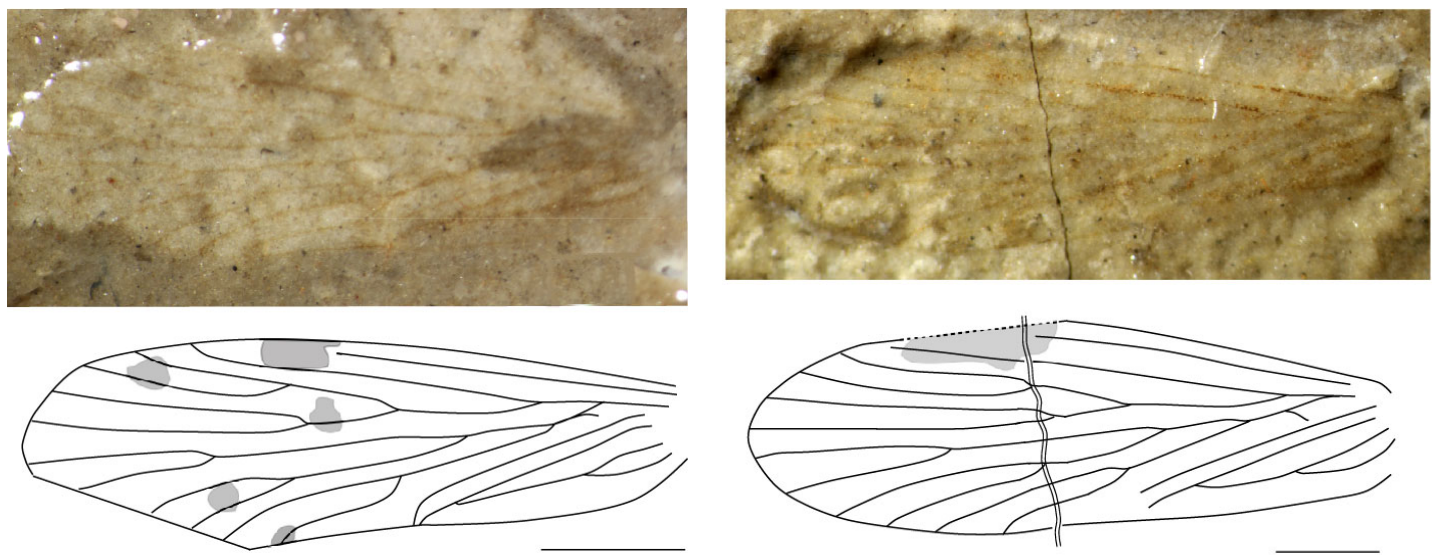

(a)

(b)
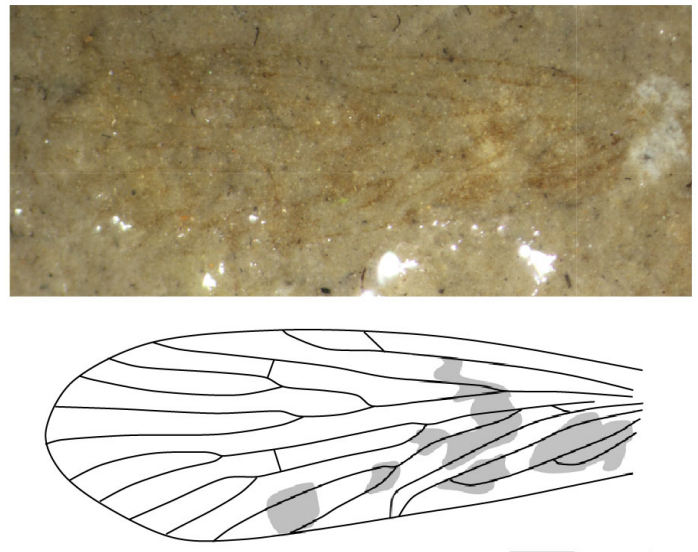

(c)

Figure 5: Previous holotypes now considered conspecific with Austaulius furcatus (Giebel, 1856). (a) "Necrotaulius apicalis" Tillyard, 1933 (NHMUK I.3081); (b) "N. stigmaticus" Tillyard, 1933 (NHMUK I.11584); (c) "N. westwoodi" Tillyard, 1933 (NHMUK I.11761), all from Wainlode Cliff, Gloucestershire. Scale bars $=1 \mathrm{~mm}$.

than anterior). M lying very close to $\mathrm{R}$ at base and fused with $\mathrm{CuA}$ shortly after leaving $\mathrm{CuP}$ for a short distance; $\mathrm{M}$ bifurcates forming two forks, the anterior shorter than the posterior (this is clearest in the counterpart of the holotype, Figure 3); one cross-vein between $\mathrm{M}$ and $\mathrm{CuA}$; $\mathrm{CuP}$ is preserved almost to the posterior margin; one cross-vein between $\mathrm{CuA}$ and CuP. Additional cross-vein between 1A and $2 \mathrm{~A}$ near the base. Hindwings are poorly preserved but, in the counterpart, it seems that the venation is similar except there are three veins in the medial system rather than four, the posterior vein being simple. Colour pattern evident in most specimens although it may be faint.

Remarks. The remaining species described by Tillyard [9] (N. westwoodi, N. stigmaticus, and N. apicalis) all show the fusion of $\mathrm{M}$ and $\mathrm{Cu}$ typical of Austaulius. The backward bent $\mathrm{CuP}$ is preserved in the holotype and in the previous holotypes of $N$. apicalis and $N$. westwoodi; in N. stigmaticus this character is not preserved but it can be assumed by its absence that it was desclerotised. Although the type specimens are less well preserved than the type of $A$. furcatus, and not all the crossveins are visible, there is nothing significant to distinguish any of them as being different from $A$. furcatus, so they are considered to be junior synonyms. Tillyard drew the outlines of $N$. stigmaticus and $N$. apicalis with a more pointed tip than is apparent from the specimens. The holotypes of $N$. westwoodi, $N$. stigmaticus, and N. apicalis were collected from Wainlode Cliff and the holotype of $A$. furcatus was collected from Aust Cliff. Both localities were reported in Zhang et al. [18] as Early Jurassic $\left(\mathrm{J}_{1}\right)$ but the insect bearing horizon at these localities is found in the Penarth Group which is Late Triassic in age.

$$
\begin{aligned}
& \text { Austaulius haustrum sp. nov. } \\
& \text { urn:lsid:zoobank.org:act:09920586-B224-437C- } \\
& \text { A567-46808E8D1AAE }
\end{aligned}
$$

Holotype. NHMUK II 3103 a and b (Figure 6), Sinemurian, Turneri Chronozone, Brooki Bed, Monmouth Beach, Lyme Regis, Dorset, UK. Collected by R. A. Coram.

Etymology. Haustrum is the original Latin word for "haustellum" indicating the presence of this character in the holotype. 


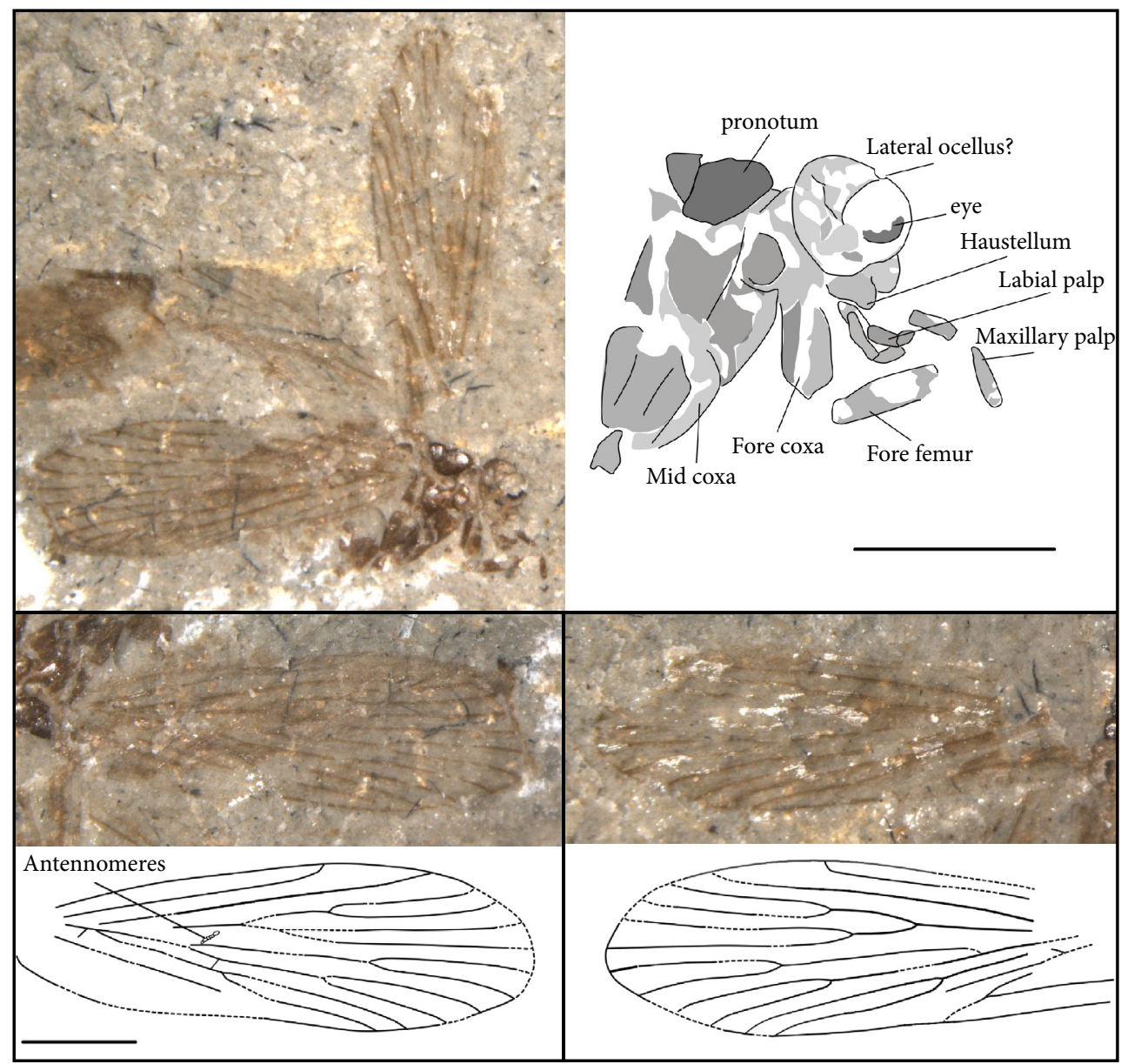

FIgURE 6: Holotype of Austaulius haustrum gen. et sp. nov. (NHMUK II 3103 a and b) from Monmouth Beach, Lyme Regis, Dorset. Bottom left figure is the right forewing of the holotype flipped so the costal margin is on top. Scale bars $=1 \mathrm{~mm}$.

Diagnosis. Forewing length $4.7 \mathrm{~mm}$, width $1.8 \mathrm{~mm}$. Anterior fork (F1) of Rs branches distally of branching point of posterior fork (F2), much further than in A. furcatus.

Description. The holotype is a well preserved specimen with two forewings and a partial hind wing, thorax, head, some antennomeres, some leg segments, maxillary and labial palps, and the haustellum. Pronotum is small and heavily sclerotized. Fore coxa broader than the fore femur, mid coxa appears broader but not well preserved. Head is hypognathous. Maxillary palps are longer than the labial palps, two elongate segments of one palp preserved; three labial palp segments preserved (as well as another unidentified palp with two segments), attached to the haustellum. Eye socket appears large, but only a small portion of the actual eye is preserved and there is a groove above the eye where the lateral ocellus would be found. The apex of $\mathrm{CuP}$ appears to be desclerotised as in A. furcatus.

Remarks. This specimen was figured by Coram ([56], Figure 5) as a "Caddisfly-like necrotauliid." This is the only necrotauliid specimen to preserve the haustellum. As discussed in the introduction, this is the only specified adult synapomorphy for Trichoptera [22] and suggests that the Necrotauliidae are trichopterans.

\section{Discussion}

The necrotauliids have been considered to be primitive trichopterans, advanced stem-amphiesmenopterans, and a paraphyletic assemblage of primitive trichopterans, primitive lepidopterans, and stem-amphiesmenopterans. Therefore, necrotauliids represent an important group for understanding the evolution of the Amphiesmenoptera but much of the taxonomy of the group was in need of revision. Ansorge [12, 14] revised the Upper Lias German material, restricting the Necrotauliidae to two species and removing the family from Trichoptera, suggesting that Liadotaulius (Philopotamidae) was the only true trichopteran from the German Upper Lias.

English Necrotaulius are sparse and only three specimens were identified as N. parvulus; this is also the only species of this genus from the Lias of England. Most of the specimens previously attributed to Necrotaulius are herein considered to belong to a separate and older genus (Austaulius) which, 
based on the current fossil record, survived the end Triassic mass extinction but is not recorded after the appearance of Necrotaulius in England. This genus can be separated from Necrotaulius by the fusion of $\mathrm{M}$ and $\mathrm{CuA}$ near the base for a short distance.

The holotype of A. haustrum is well preserved and exhibits several mouthpart characters that are rare in amphiesmenopteran fossils. The head is visible with a partial eye preserved; ventral to the main head capsule there is a structure from which the labial palps originate. The labial palps appear to be formed of three elongated segments and would probably be about half the length of the maxillary palps as in extant Trichoptera [57]. The haustellum is the only suggested autapomorphy for adult Trichoptera [25] and we propose that the structure in the holotype of A. haustrum ventral to the head and attached to the labial palps is the haustellum. It is a composite of the prelabium and the hypopharynx which forms a short proboscis used for sucking up liquids [22]; it is not homologous to the structure of the same name in Diptera [58]. For an in-depth description of the morphology of an adult trichopteran head see [58]; [25] provides a lateral photograph of a trichopteran head with a short haustellum and palps similar to those seen in the holotype of A. haustrum. The presence of a haustellum in the holotype of A. haustrum suggests that the family Necrotauliidae belongs to the Trichoptera.

\section{Conflicts of Interest}

None of the authors have conflicts of interest to declare.

\section{Acknowledgments}

Special thanks are due to the lead author's main Ph.D. supervisor, Mike Benton, at the University of Bristol for advice and support throughout the project. Many thanks are due to the curators of collections for access to the specimens: Claire Mellish at NHMUK, Sarah King and Stuart Ogilvy at YORYM, Eliza Howlett at OUMNH, Dennis Parsons at TTNCM, Stefan Meng and Jörg Ansorge at EMAUG, Alexander Rasnitsyn and Irina Sukacheva at PIN, and Bo Wang at NIGPAS. Also, thanks are due to the Natural Environment Research Council (NERC) for funding the lead author's Ph.D. project from which this study was made possible (Studentship no. NE/L002434/1).

\section{References}

[1] P. J. Gullen and P. S. Cranston, The Insects, Wiley-Blackwell, Chichester, UK, 2010.

[2] J. C. Morse, "Phylogeny of Trichoptera," Annual Review of Entomology, vol. 42, pp. 427-450, 1997.

[3] W. Wichard, "Overview and descriptions of Trichoptera in Baltic amber," in Spicipalpia and Integripalpia, Verlag, Kessel, Germany, 2013.

[4] J. Huxley and P. C. Barnard, "Wing-scales of Pseudoleptocerus chirindensis Kimmins (Trichoptera: Leptoceridae)," Zoological Journal of the Linnean Society, vol. 92, no. 3, pp. 285-312, 1988.
[5] E. F. Riek, "The marine caddisfly family chathamiidae (Trichoptera)," Australian Journal of Entomology, vol. 15, no. 4, pp. 405-419, 1977.

[6] D. Grimaldi and M. S. Engel, Evolution of the Insects, Cambridge University Press, 2005.

[7] A. Handlirsch, Die fossilen Insekten und die Phylogenie der rezenten Formen, Wilhelm Engelmann, Leipzig, Germany, 1906-1908.

[8] C. Giebel, Fauna der Vorwelt mit steter Berücksichtigung der lebenden, Thiere, Leipzig, Germany, 1856.

[9] R. J. Tillyard, "The Panorpoid complex in the British Rhaetic and Lias," in Fossil Insects, British Museum Natural History, vol. 3, pp. 1-79, 1933.

[10] A. Handlirsch, "Neue Untersuchungen über die fossilen Insekten mit Ergänzungen und Nachträgen sowie Ausblicken auf phylogenetische, palaeogeographische und allgemein biologische Probleme," Annalen des Naturhistorischen Museums in Wien, vol. 49, pp. 1-240, 1939.

[11] F. C. J. Fischer, "Comments on the nomenclature of some fossil Trichoptera," Entomological Reports, vol. 22, pp. 5-6, 1962.

[12] J. Ansorge, "Revision of the "Trichoptera" described by Geinitz and Handlirsch from the Lower Toarcian of Dobbertin (Germany) based on new material," in Proceedings of the 10th International Symposium on Trichoptera, vol. 15, pp. 55-74, 2002.

[13] A. P. Rasnitsyn and D. L. J. Quicke, History of Insects, Kluwer Academic Publishers, Dordrecht, Netherlands, 2002.

[14] J. Ansorge, "Upper Liassic Amphiesmenopterans (Trichoptera + Lepidoptera) from Germany a review," Acta Zoologica Cracoviensia, vol. 46, pp. 285-290, 2003.

[15] D. S. Aristov, A. S. Bashkuev, V. K. Golubev et al., "Fossil insects of the middle and upper Permian of European Russia," Paleontological Journal, vol. 47, no. 7, pp. 641-832, 2013.

[16] J.-C. Sohn, C. Labandeira, D. Davis, and C. Mitter, "An annotated catalog of fossil and subfossil Lepidoptera (Insecta: Holometabola) of the world," Zootaxa, no. 3286, pp. 1-132, 2012.

[17] W. Hao and H. Diying, "A new species of Liadotaulius (Insecta: Trichoptera) from the Middle Jurassic of Daohugou, Inner Mongolia," Acta Geologica Sinica, vol. 86, no. 2, pp. 320-324, 2012.

[18] W. Zhang, C. Shih, and D. Ren, "Two new fossil caddisflies (Amphiesmenoptera: Trichoptera) from the Middle Jurassic of northeastern China," Alcheringa, vol. 41, no. 1, pp. 22-29, 2017.

[19] D. B. Nicholson, P. J. Mayhew, and A. J. Ross, "Changes to the fossil record of insects through fifteen years of discovery," PLoS ONE, vol. 10, no. 7, Article ID e0128554, 2015.

[20] Y. Liu, W. Zhang, Y. Yao, and D. Ren, "A new fossil of necrotauliidae (Insecta: Trichoptera) from the jiulongshan formation of china and its taxonomic significance," PLOS ONE, vol. 9, no. 12, Article ID el14968, 2014.

[21] H. H. Ross, "The Evolution and Past Dispersal of the Trichoptera," Annual Review of Entomology, vol. 12, no. 1, pp. 169206, 1967.

[22] R. W. Holzenthal, R. J. Blahnik, A. L. Prather, and K. M. Kjer, “Order Trichoptera Kirby, 1813 (Insecta), Caddisflies," Zootaxa, no. 1668, pp. 639-698, 2007.

[23] J.-P. Haenni, "North African Dilophus Meigen, with description of D. maghrebensis n.sp. (Diptera: Bibionidae)," Insect Systematics and Evolution, vol. 12, no. 4, pp. 429-432, 1981.

[24] F. M. Carpenter, "Revision of the Nearctic Raphidiodea (Recent and Fossil)," Proceedings of the American Academy of Arts and Sciences, vol. 71, no. 2, p. 89, 1936. 
[25] M. Kubiak, F. Beckmann, and F. Friedrich, "The adult head of the annulipalpian caddisfly Philopotamus ludificatus Mclachlan, 1878 (Philopotamidae), mouthpart homologies, and implications on the ground plan of Trichoptera," Arthropod Systematics and Phylogeny, vol. 73, no. 3, pp. 351-384, 2015.

[26] W. Mey, W. Wichard, P. Müller, and B. Wang, “The blueprint of the Amphiesmenoptera-Tarachoptera, a new order of insects from Burmese amber (Insecta, Amphiesmenoptera)," Mitteilungen aus dem Museum für Naturkunde in Berlin, vol. 20, no. 2, pp. 129-145, 2017.

[27] N. P. Kristensen, "Early evolution of the Trichoptera+ Lepidoptera lineage: phylogeny and the ecological scenario," Mémoires Du Muséum D’histoire Naturelle, vol. 173, pp. 253-271, 1997.

[28] S. R. Schachat and R. L. Brown, "Forewing color pattern in Micropterigidae (Insecta: Lepidoptera): homologies between contrast boundaries, and a revised hypothesis for the origin of symmetry systems," BMC Evolutionary Biology, vol. 16, no. 1, article no. 116, 2016.

[29] F. M. Carpenter, "Treatise on Invertebrate Paleontology Part R, Arthropoda 4: Superclass Hexapoda," in Geological Society of America, Kansas, USA, 1992.

[30] J. O. Westwood, "Contributions to fossil entomology," The Quarterly journal of the Geological Society of London, vol. 10, no. 1-2, pp. 378-396, 1854.

[31] F. E. Geinitz, "The law of Dobbertin in Mecklenburg and its fossils," Journal of the German Geological Society, vol. 32, pp. 510-535, 1880.

[32] S. H. Scudder, "Index to the known fossil insects of the world including myriapods and arachnids," Bulletin of the United States Geological Survey, vol. 71, pp. 1-744, 1891.

[33] P. B. Brodie, A History of the fossil insects in the secondary rocks of England. Accompanied by a particular account of the strata in which they occur, and of the circumstances connected with their preservation, John van Voorst, London, UK, 1845.

[34] J. Szwedo, T. Bourgoin, and F. Lefebvre, "Fossil Planthoppers (Hemiptera: Fulgoromorpha) of the world: An annotated catalogue with notes on Hemiptera classification," in Museum and Institute of Zoology, Polish Academy of Sciences, 2004.

[35] R. S. Kelly, A. J. Ross, and E. A. Jarzembowski, "Earwigs (Dermaptera) from the Mesozoic of England and Australia, described from isolated tegmina, including the first species to be named from the Triassic," Earth and Environmental Science Transactions of the Royal Society of Edinburgh, vol. 107, no. 2-3, pp. 129-143, 2018.

[36] R. S. Kelly, A. J. Ross, and P. Davidson, "Mesozoic Holcoptera (Coleoptera: Coptoclavidae) from England and the United States," Proceedings of the Geologists' Association, vol. 128, no. 4, pp. 659-674, 2017.

[37] L. M. Hauser and D. M. Martill, "Evidence for coelacanths in the Late Triassic (Rhaetian) of England," Proceedings of the Geologists' Association, vol. 124, no. 6, pp. 982-987, 2013.

[38] G. Warrington and A. Whittaker, "The Blue Anchor Formation (late Triassic) in Somerset," Proceedings - Ussher Society, vol. 6, no. 1, pp. 100-107, 1984.

[39] D. Palmer, "An introduction to the fossil arthropods of Great Britain," in Joint Nature Conservation Committee, E. A. Jarzembowski, D. J. Siveter, and D. Palmer, Eds., Peterborough, England, 2010.

[40] M. J. Simms, N. Chidlaw, N. Morton, and K. N. Page, British Lower Jurassic Stratigraphy, Geological Conservation Review
Series, vol. 30, Joint Nature Conservation Committee, Peterborough, UK, 2004.

[41] A. J. M. Barron, M. G. Sumbler, A. N. Morigi et al., "Geology of the Moreton-in-Marsh District: Sheet Description of the British Geological Survey 1:50000 Series Sheet 217 (England and Wales)," in British Geological Survey, London, UK, 2002.

[42] M. Williams, M. J. Benton, and A. Ross, “The strawberry bank Lagerstätte reveals insights into early Jurassic life," Journal of the Geological Society, vol. 172, no. 6, pp. 683-692, 2015.

[43] S. G. Kiriakoff, A classification of the Lepidoptera and related groups with some remarks on taxonomy, vol. 15, Biologisch Jaarboek, Antwerpen, Belgium, 1948.

[44] W. Kirby, "VI. Strepsiptera, a new Order of Insects proposed; and the Characters of the Order, with those of its Genera, laid down.," Transactions of the Linnean Society of London, vol. 11, no. 1, pp. 86-122, 1813.

[45] E. F. Riek, "Fossil insects from the Triassic beds at Mt. Crosby, Queensland," Australian Journal of Zoology, vol. 3, no. 4, pp. 654-691, 1955.

[46] F. E. Geinitz, "Ueber die Fauna des Dobbertiner Lias. Zeitschrift der deutschen geologischen," in Gesellschaft, pp. 566-583, 1884.

[47] Y. C. Hong, Insecta. In: Palaeontological Atlas of North China, II, Geological Publishing House, Beijing, China, 1984.

[48] E. A. Jarzembowski, "New insects from the Weald Clay of the Weald," Proceedings - Geologists' Association, vol. 102, no. 2, pp. 93-108, 1991.

[49] H. Goss, "The Insect Fauna of the Secondary or Mesozoic Period, and the British and Foreign Formations of that Period in which Insect Remains have been Detected," Proceedings of the Geologists' Association, vol. 6, no. 3, pp. 116-150, 1879.

[50] H. B. Woodward, "The Jurassic rocks of Britain," in The Lias of England and Wales (Yorkshire Excepted), vol. 3, HM Stationery Office, London, UK, 1893.

[51] R. Willmann, "Mecoptera (Insecta, Holometabola) Fossilum Catalogus," Animalia, vol. 124, p. 139, 1978.

[52] I. D. Sukatsheva, "Yurskie rucheyniki yuzhnoy Sibiri," in Yurskie Nasekomye Sibiri i Mongolii (Jurassic Insects of Siberia and Mongolia), Trudy Paleontologicheskogo Instituta Akademii Nauk SSSR, A. P. Rasnitsyn, Ed., pp. 115-119, 1985.

[53] E. A. Jarzembowski, "Arthropods -2: Insects," in Fossil of the Rhaetian Penarth Group, A. Swift and D. M. Martill, Eds., pp. 149-160, Palaeontological Association, London, UK, 1999.

[54] E. A. Jarzembowski and D. Palmer, "Mesozoic fossil arthropods," in Fossil arthropods of Great Britain, Geological Conservation Review Series, E. A. Jarzembowski, D. J. Siveter, D. Palmer, and P. A. Selden, Eds., vol. 35, Joint Nature Conservation Committee, Peterborough, UK, 2010.

[55] B. J. Pyrah, "Catalogue of type and figured fossils in the Yorkshire museum: Part 1," Proceedings of the Yorkshire Geological Society, vol. 41, no. 1, pp. 35-47, 1976.

[56] R. A. Coram, "New insect fossils from the Lower Lias (Lower Jurassic) of West Dorset," in Proceedings of the Dorset Natural History and Archaeological Society, vol. 135, pp. 181-188, 2014.

[57] I. D. Sukatsheva, "New caddis-flies (Trichoptera) from the Mesozoic of Soviet Central Asia," Paleontological Journal, vol. 3, pp. 100-107, 1973.

[58] M. I. Crichton, "The Structure and Function of the Mouth Parts of Adult Caddis Flies (Trichoptera)," Philosophical Transactions of the Royal Society B: Biological Sciences, vol. 241, no. 677, pp. 45-91, 1957. 


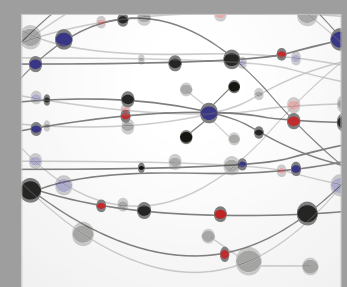

The Scientific World Journal
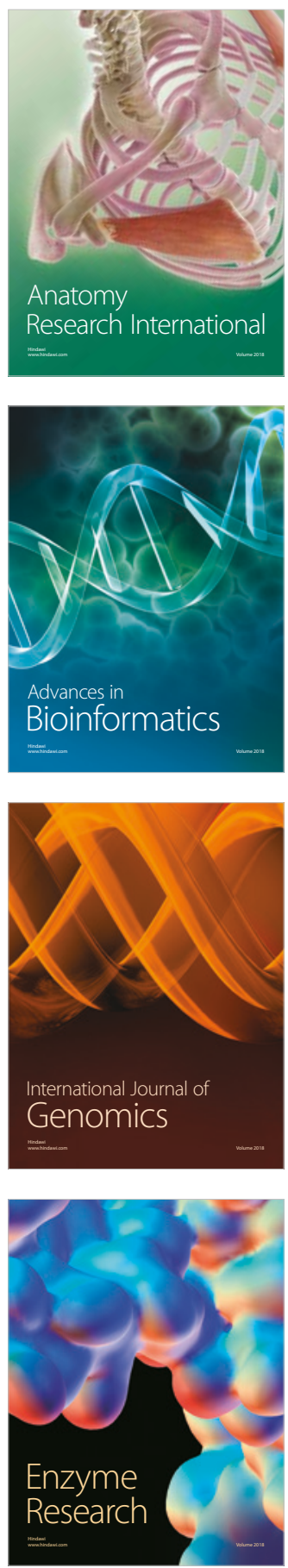
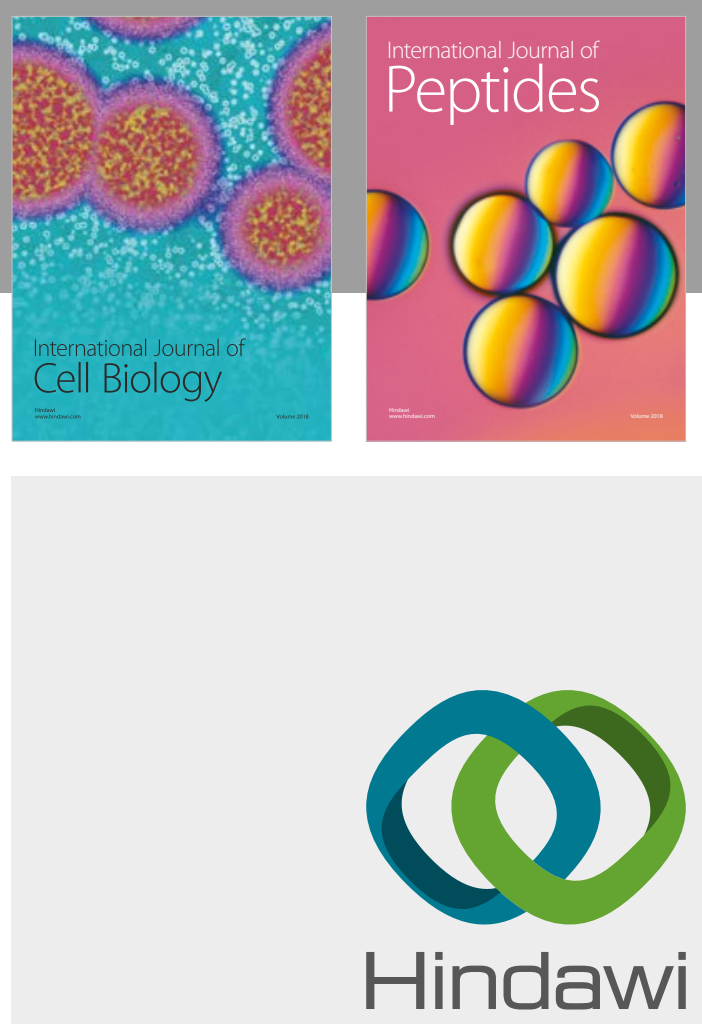

Submit your manuscripts at

www.hindawi.com
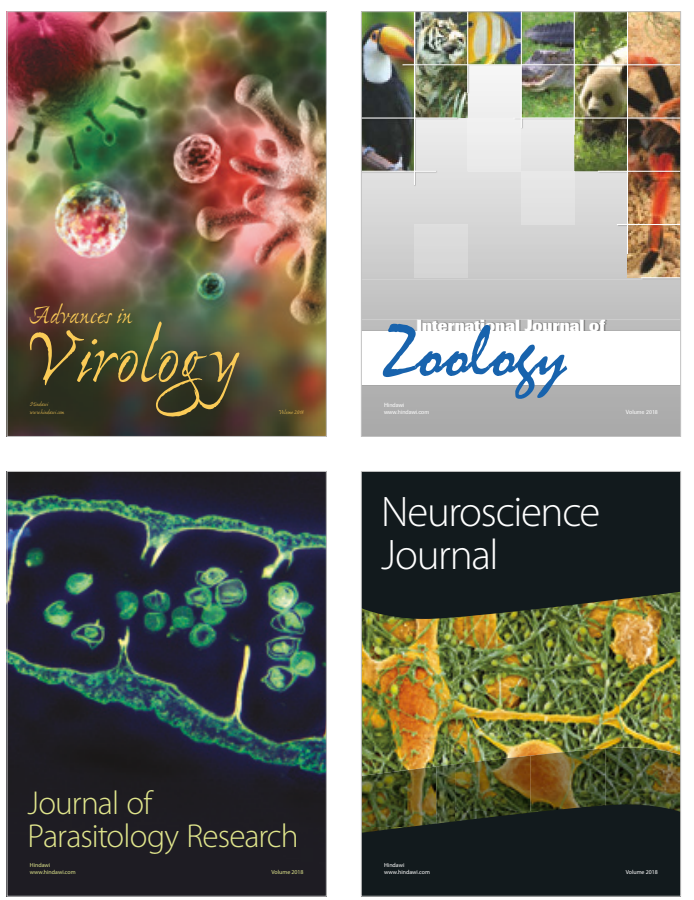
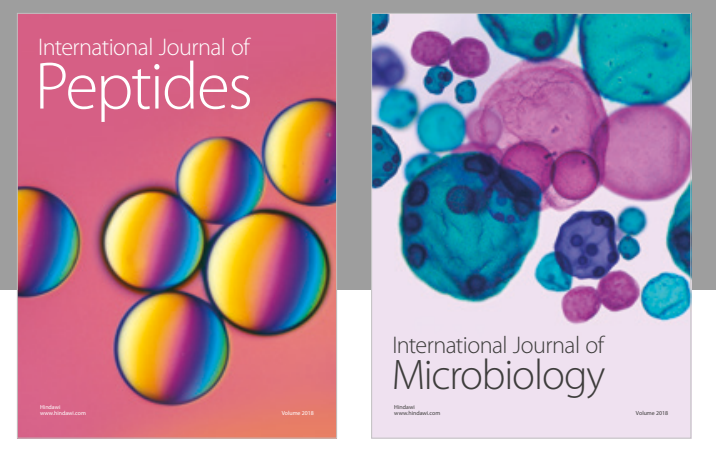

nternational Journal of Microbiology
Journal of
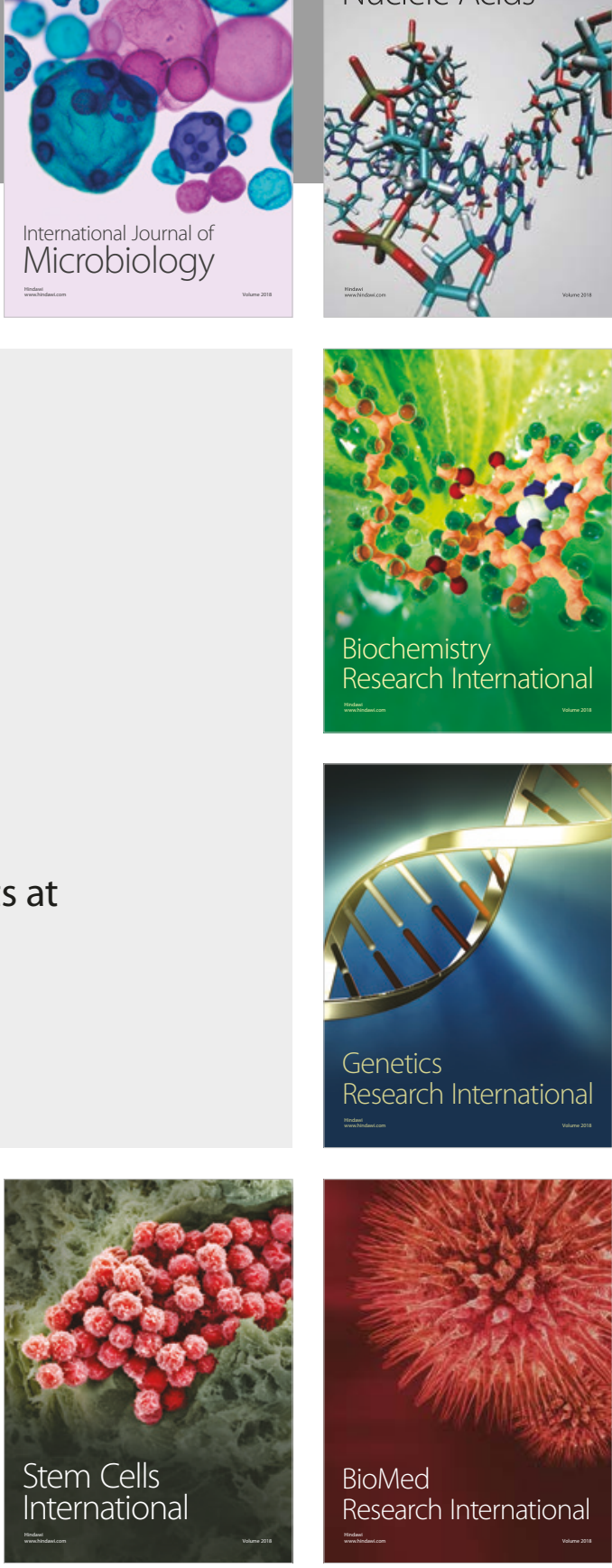
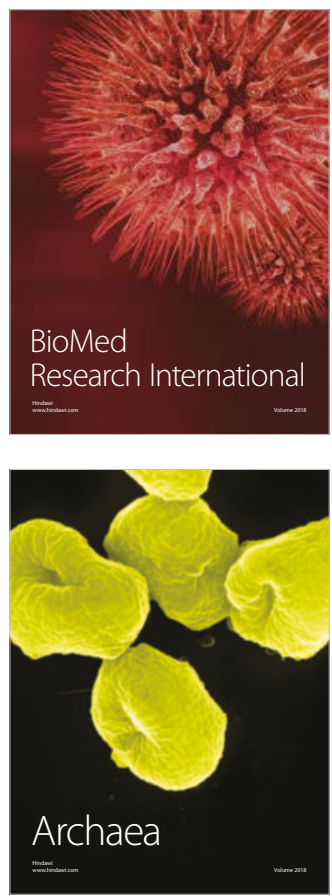